\title{
Guillaume Maeau, Corday contre Marat. Deux siècles d'images
}

\section{Annie Duprat}

\section{(2) OpenEdition \\ Journals}

Édition électronique

URL : https://journals.openedition.org/ahrf/11751

DOI : $10.4000 /$ ahrf. 11751

ISSN : 1952-403X

Éditeur :

Armand Colin, Société des études robespierristes

Édition imprimée

Date de publication : 1 septembre 2010

Pagination : 213

ISBN : 978-2-200-92633-5

ISSN : 0003-4436

Référence électronique

Annie Duprat, «Guillaume Maeau, Corday contre Marat. Deux siècles d'images », Annales historiques de la Révolution française [En ligne], 361 | juillet-septembre 2010, mis en ligne le 22 mars 2011, consulté le 23 avril 2022. URL : http://journals.openedition.org/ahrf/11751 ; DOI : https://doi.org/10.4000/ahrf. 11751

Ce document a été généré automatiquement le 23 avril 2022

Tous droits réservés 


\title{
Guillaume Maeau, Corday contre Marat. Deux siècles d'images
}

\author{
Annie Duprat
}

\section{RÉFÉRENCE}

Guillaume Maeau, Corday contre Marat. Deux siècles d'images, Vizille, Musée de la Révolution française, et Versailles, Éditions Artlys, 2009, 80 p., ISBN 978-2-85495-377-0, $15 €$

1 Le retour des personnages dans l'écriture de l'histoire de la Révolution française ne se dément pas, comme en témoigne à présent, après la vague rose et sucrée des expositions multiples sur Marie-Antoinette, l'actualité plus rouge et sanglante de Charlotte Corday. Guillaume Mazeau, auteur d'une thèse audacieuse et talentueuse, très rapidement éditée sous le titre Le bain de l'histoire. Charlotte Corday et l'attentat contre Marat, 1793-2009, (Seyssel, Champ Vallon, coll. La chose publique, 2009) a contribué au montage de l'exposition Corday contre Marat. Les discordes de l'histoire, au Musée de la Révolution française de Vizille (26 juin-28 septembre 2009). Il en a réalisé un bref catalogue très suggestif. En effet, tandis que l'édition de sa thèse souffrait de la piètre qualité des rares images reproduites (nous savons tous combien il est difficile - et onéreux - de publier des livres illustrés !) ce catalogue, léger par la taille mais écrit dans une langue qui allie la clarté à l'érudition, nous donne toutes les clés de compréhension du " phénomène Corday ». En effet, et l'exposition Crime et châtiment au Musée d'Orsay (16 mars-10 juin 2010) le démontre à nouveau, la figure de Charlotte Corday a dépassé celle de sa victime. Dans son livre, Guillaume Mazeau démontait tous les fils qui ont transformé un assassinat politique impensable lorsqu'il s'est produit (en juillet 1793, dans le huis clos de l'appartement privé de Marat) en une histoire controversée et contradictoire. Par exemple, en 1889, les Guyanais ont nommé «la reine Charlotte " la statue de la République de la place des Palmistes à Cayenne, qui était en réalité une figure de Marianne des plus traditionnelles! De la jeune inconnue $a$ priori guère versée dans les débats révolutionnaires, venue à Paris dans l'unique but 
d'assassiner le directeur du journal L'Ami du peuple il n'est guère question dans ce catalogue riche d'une centaine de reproductions. Nous sommes placés ici au cœur de la construction d'un mythe qui culmine avec les huiles et les dessins de Kokoschka ou de Picasso.

2 L'ouvrage, assorti d'un précieux index des artistes, est divisé en trois grandes parties, dont les subdivisions résonnent comme un scénario de film et résument bien le propos. Dans «Marat: héros ou anti-héros? ? l'auteur examine les morts de Marat, comme patriote, comme martyr, comme icône mais aussi la figure du terroriste Marat. La seconde partie "Unions fatales ", reprend les images d'une guerre civile dont le sens politique n'a cessé d'être incertain; on y parcourt le lieu du crime, représenté différemment, ainsi que les gestes de la criminelle, ce qui révèle l'ambigüité de son acte. La dernière partie, enfin, « Charlotte Corday : une obsession nationale » est la plus neuve puisqu'elle parcourt les $\mathrm{XIX}^{\mathrm{e}}$ et $\mathrm{XX}^{\mathrm{e}}$ siècles pour, tour à tour, montrer le visage d'une criminelle se métamorphoser en effigie politique nationale, l'âme de la France, la flamme de la résistance à l'oppression, puis en femme fatale... Qui l'eût cru, à regarder la caricature de Gillray (catalogue p. 71)?

Ce petit livre est un complément nécessaire au Bain de l'histoire. 